TORRES, A.C.; FERREIRA, A.T.; WIDHOLZER, C.F.N.; ROMANO, E.; PETERS, J.A. Expressão eficiente do gene reporter $\beta$-glucuronidase nos tecidos vasculares de batata (Solanum tuberosum L.) utilizando de um promotor específico (BRA3) de Agrobacterium rhizogenes. Horticultura Brasileira, Brasília, v. 21, n. 2, p. 176-179, abril/junho 2003 .

\title{
Expressão eficiente do gene reporter $\beta$-glucuronidase nos tecidos vasculares de batata (Solanum tuberosum L.) utilizando de um promotor específico (BRA3) de Agrobacterium rhizogenes
}

\author{
Antonio Carlos Torres ${ }^{1}$; Adriana T. Ferreira ${ }^{2}$; Carlos F. N. Widholzer ${ }^{2}$; Eduardo Romano ${ }^{3}$ José A. Peters $^{2}$ \\ ${ }^{1}$ Embrapa Hortaliças, C. Postal 218, $70359-979$ Brasília, DF; ${ }^{2}$ UFPEL, C. Postal 354, 96010-900 Pelotas-RS; ${ }^{3}$ Embrapa Recursos \\ Genéticos e Biotecnologia, C. Postal 02372, 70770-9000 Brasília-DF; E.mail: torres@cnph.embrapa.br
}

\section{RESUMO}

Promotores tecido-específico controlam a transcrição de genes em diferentes tecidos vegetais bem como em diferentes estádios de desenvolvimento da planta, levando à indução de distintos níveis de atividade transiente e/ou estável do gene. Tais promotores podem ser empregados para a expressão seletiva de genes de interesse. $\mathrm{O}$ promotor rol A de Agrobacterium rhizogenes, por exemplo, é floemaespecífico, sugerindo que possa ser empregado em estratégias de defesa de plantas que são infectadas por vírus com replicação restrita ao floema. A expressão do gene marcador da ß-glucuronidase ( $g u s)$ dirigido pelo promotor rol A (pBRA3) foi observada em plantas transgênicas de batata (cvs. Macaca e Baronesa). Entrenós e secções de folhas foram submetidos ao cocultivo com A. tumefaciens. A atividade do gene gus avaliada em brotações resistentes à canamicina não se restringiu ao floema (alto nível de expressão do gene), mas também se manifestou no xilema dos caules. As expressões transiente e estável são, no entanto, tecido-específicas, localizadas sobretudo no sistema vascular de entrenós e ausente em raízes e folhas. As plantas gus positivas foram micropropagadas, plantadas em casa de vegetação e avaliadas por PCR, utilizando-se 'primers' específicos para o gene $n p t$ II. Nenhuma alteração fenotípica foi observada em plantas transgênicas, em relação às não transformadas.

Palavras-chave: Agrobacterium tumefaciens, Solanum tuberosum, transformação genética, expressão do gene gus.

\section{ABSTRACT}

Efficient expression of $\beta$-glucuronidase reporter gene in vascular tissue of potato (Solanum tuberosum L.) utilizing a specific promoter (BRA3) from Agrobacterium rhizogenes)

Tissue-especific promoters allow the modulation of gene transcription in different tissue types as well as in different stages of plant development, leading different levels of transient and stable activity of the gene product. These promoters have been employed for selective gene expression. The Agrobacterium rhizogenes rol A gene promoter (BRA3) controls phloem-specific expression indicating that this promoter might have an important role in plant defense strategies against virus which replicated only in the phloem. The expression of $\beta$-glucuronidase ( $g u s$ ) activity drived by BRA3 promoter was observed in transgenic potato plants (cvs Macaca and Baronesa). Entrenodes and leaf explants were infected and cocultivated with $A$. tumefaciens. The regeneration of putative transformants was in medium with $50 \mathrm{mg} . \mathrm{L}^{-1}$ of kanamycin. High frequency of transformants based upon kanamycin resistance and gus expression was obtained. All gus positive plants showed blue staining in vascular bundle (phloem and xylem). PCR analysis showed the amplification of npt II. No conspicuous phenotipic alteration was observed when comparing transgenic vs nontransgenic plants.

Keywords: Agrobacterium tumefaciens, Solanum tuberosum, genetic transformation, gus expression gene.

\section{(Recebido para publicação em 10 de janeiro de 2002 e aceito em 03 de abril de 2003)}

$\mathrm{O}$ vírus do enrolamento das folhas da batata (PLRV, Potato leafroll virus) é um luteovirus, que replica em células floemáticas, sendo transmitido por afídeos de maneira persistente (Tamada \& Harrison, 1981; Harrison, 1984). Os sintomas de infecção com PLRV manifestam-se, inicialmente, nas folhas inferiores e, posteriormente, se difundem por toda a planta. Plantas jovens infectadas se tornam enfraquecidas e atrofiadas e os tubérculos produzidos não podem ser utilizados para plantios comerciais. Além disso, a principal espécie vetora Myzus persicae Sulzer, já adquiriu resistência a alguns inseticidas registrados para uso em Solanum tuberosum L. (Field \& Foster, 2002).
$\mathrm{Na}$ cultura da batata, as estratégias para reduzir perdas pela infecção viral são baseadas no uso de tubérculos livres de vírus e práticas culturais adequadas (Gugerli, 1986). Entretanto, esses procedimentos não oferecem solução permanente para o problema (Romano et al., 2001). O desenvolvimento de cultivares resistentes via melhoramento genético é dificultado devido ao fato da batata ser uma espécie tetraplóide. A tecnologia de DNA recombinante e a regeneração de plantas via cultura de tecidos têm sido usadas com sucesso para introdução de genes exógenos no genoma de várias espécies incluindo a batata (Vayda \& Belknap, 1992; Torres et al., 2000; Romano et al., 2001), per- mitindo o desenvolvimento de cultivares melhoradas em prazos mais curtos.

As principais justificativas para a utilização de promotores tecido-específicos na introdução de resistência a vírus em plantas via transformação genética são: 1) alguns vírus vegetais, tais como os luteovírus, os reovírus e a maioria dos geminivírus, replicam, exclusivamente, em tecidos floemáticos; (2) a expressão de genes de defesa na forma constitutiva aumentaria desnecessariamente, os riscos de transcapsidação ou recombinação viral em tecidos não vasculares (Green \& Alison, 1994); e 3 ) a expressão específica de genes pode reduzir a carga metabólica das plantas e evitar possíveis alterações fenotípicas 
indesejáveis já que apenas o tecido de interesse será afetado.

Nesse trabalho avaliou-se a expressão do gene gus sob o controle de um promotor específico para células do floema em dois genótipos comerciais de batata. Dois tipos de explantes de cada genótipo foram utilizados na tentativa de maximizar a regeneração e, consequentemente, otimizar a transformação.

\section{MATERIAL E MÉTODOS}

\section{Regeneração}

Entrenós e secções foliares, excisados de propágulos mantidos in vitro das cultivares de batata "Baronesa" e "Macaca", foram utilizados como explantes. O meio de cultura básico para os experimentos de regeneração e transformação, consistiu de sais minerais MS (Murashige \& Skoog, 1962) contendo, em mg.L L $^{-1}$ : sacarose, 25.000; i-inositol, 100; tiamina. $\mathrm{HCl}, 1,0$; piridoxina. $\mathrm{HCl}$, 0,5; ácido nicotínico, 0,5; glicina, 2.0; zeatina ribosídeo 3,0 ; ácido 3 indolilacético, 0,05 e ácido giberélico, 3,0 (Trinca et al., 1991).

\section{Estirpe bacteriana e inoculação}

A estirpe de Agrobacterium tumefaciens LBA4404 contendo vetor de transformação pBRA3-gus (Guivarc'h et al., 1996) foi utilizada nesse trabalho. Esse vetor possui os genes npt II ligado ao promotor da nopalina sintase e $\beta$ glucuronidase com o promotor do gene rol A cuja expressão se verifica em células transformadas do floema. A bactéria foi crescida em meio de Luria-Bertani broth (LB) (bactotriptona, 10g. $\mathrm{L}^{-1}$; extrato de levedura $5 \mathrm{~g} . \mathrm{L}^{-1}$; cloreto de sódio, 10 g.L $\mathrm{L}^{-1}$ e ágar 14 g.L $\mathrm{L}^{-1}$ ), suplementado com canamicina, $100 \mathrm{mg} . \mathrm{L}^{-1}$, spectinomicina, $300 \mathrm{mg} . \mathrm{L}^{-1} \mathrm{e}$ rifamicina $100 \mathrm{mg} . \mathrm{L}^{-1}$, pH 7,0. As culturas foram mantidas sob agitação (150 rpm), a $28^{\circ} \mathrm{C}$, por um período de 16 a 18 horas. O inóculo consistiu de culturas de $A$. tumefaciens, com 0,8 O.D (600 nm).

Entrenós e secções foliares foram imersos em suspensão bacteriana por 5 minutos. Em seguida, colocados sobre papel de filtro estéril para eliminar o excesso de bactérias e incubados em meio para cocultivo (meio básico) durante 48 horas (Trinca et al., 1991). Após o cocultivo os explantes foram colocados em meio de seleção (meio de cocultivo suplementado com $50 \mathrm{mg} . \mathrm{L}^{-1} \mathrm{de}$

Tabela 1. Percentagem de regeneração de explantes de entrenós e folhas das cultivares de batata 'Baronesa' e 'Macaca', transformadas com Agrobacterium tumefaciens contendo o vetor pBRA3-gus.

\begin{tabular}{lcccc}
\hline Tratamentos & BarE & BarF & MacE & MacF \\
\hline Controle & $80(61-92)$ & $10(3-22)$ & $90(73-98)$ & $25(17-35)$ \\
PBra3-gus & $18(11-27)$ & $0(0-7)$ & $23(15-32)$ & $3(1-8)$ \\
\hline
\end{tabular}

*Números em parêntesis significam $95 \%$ de intervalo de confiança. BarE: entrenós da cv. Baronesa; BarF: explantes foliares da cv. Baronesa; MacE: entrenós da cv. Macaca e MacF: explantes foliares da cv. Macaca.

canamicina; $500 \mathrm{mg} . \mathrm{L}^{-1}$ de carbenicilina; e $100 \mathrm{mg} . \mathrm{L}^{-1}$ de cefotaxima). A eficiência de transformação dos explantes foi avaliada pela expressão transiente e estável do gene gus nos tecidos dos propágulos regenerados. As brotações dos explantes transformados foram incubadas no substrato 5-bromo-4-cloro-3indolil glucuronídeo (X-Gluc: Jersey Lab and Glove Supply. Livingstone, NJ), de acordo com Jefferson et al. (1987). Secções de caule, pecíolos, folhas, raízes e tubérculos, provenientes de plantas desenvolvidas em casa de vegetação, foram imersas no substrato 5-bromo-4-cloro-3indolil glucuronídeo (X-Gluc: Jersey Lab and Glove Supply. Livingstone. NJ), de acordo com Jefferson et al. (1987) e incubadas no escuro a $37^{\circ} \mathrm{C}$, por $24 \mathrm{~h}$. Após este período foi retirado o tampão de reação e adicionado etanol $70 \%$ para interromper a reação e remover a clorofila dos tecidos, permitindo a visualização da coloração.

Para analisar a expressão do gene gus dirigida pelo promotor rolA (tecido-específica), realizou-se cortes anatômicos de material fixado em uma mistura de formolaldeido, ácido acético, álcool etílico e água (FAA) e montados nas lâminas de vidro com gelatina glicerinada (Sass, 1940). Os vários órgãos foram seccionados transversalmente e a mão livre. As secções foram observadas e fotografadas em estereo-microscópio Olympus (SZH10) e em um microscópio Olympus (BX50), utilizando-se técnicas de campo-claro e contraste interferencial.

O DNA total de plantas resistentes a canamicina coletadas aleatoriamente, foi extraído a partir do procedimento descrito por Edwards et al. (1991). Foi utilizado teste de reação em cadeia da polimerase (PCR, polymerase chain reaction) com primers específicos para verificar a presença do gene neo. Foram utilizadas reações de $25 \mathrm{ml}$, para cada amostra de DNA, contendo $2,5 \mathrm{ml}$ de tampão de reação 10X (500 mM de $\mathrm{KCl}$; $15 \mathrm{mM}$ de $\mathrm{MgCl}_{2}$ e $100 \mathrm{mM}$ de Tris$\mathrm{HCl} \mathrm{pH} 9,0), 2,5 \mathrm{mM}$ de cada dNTP, 10 $\mathrm{mM}$ de cada primer, 5 unidades de Taq DNA polimerase (Pharmacia Biotech), $2 \mathrm{ml}$ do DNA extraído, água destilada estéril para completar o volume final e óleo mineral para evitar evaporação das amostras durante os ciclos de aquecimento e resfriamento.

O par de primers sintéticos utilizados, denominados npt 1 (5' - GAG GCT ATT CGG CTA TGA CTG - 3') e npt 2 (5' - TCG ACA AGA CCG GCT TCC ATC - 3'), delimitam uma região de 410 pares de base da sequiência codificante do gene neo. A amplificação foi realizada em um termociclador Perkin Elmer Cetus 9700 DNA, onde os ciclos de temperatura utilizados foram 5 min a $94^{\circ} \mathrm{C}$, seguido de 35 ciclos de $1 \mathrm{~min}$ a $94^{\circ} \mathrm{C}$; 1 $\min$ a $55^{\circ} \mathrm{C}$ e $1 \min$ a $72^{\circ} \mathrm{C}, 7$ min finais a $72^{\circ} \mathrm{C}$ e mantidos a $4^{\circ} \mathrm{C}$. Com base no tamanho do fragmento de DNA, o produto do PCR foi separado por eletroforese em gel de agarose $1 \%$ com tampão TBE 1X (10X: 0,89 M de Trisbase; 0,89 M de ácido bórico e 0,02 M EDTA) e $1 \%$ p.v. de brometo de etídio. Foi utilizado como marcador molecular $1 \mathrm{mg}$ de DNA $1 \mathrm{~kb}$ Ladder.

\section{RESULTADOS E DISCUSSÃO}

\section{Regeneração}

Nas condições estabelecidas, foi observado que a percentagem de regeneração de brotações foi influenciada pelo genótipo e tipo de explante utilizado. A regeneração dos explantes da cv. Macaca foi superior aos da cv. Baronesa. Os entrenós apresentaram um número maior de brotações que os explantes foliares (Tabela 1). Maior percentagem de regeneração foi observada em explantes de entrenós de ambas as cul- 


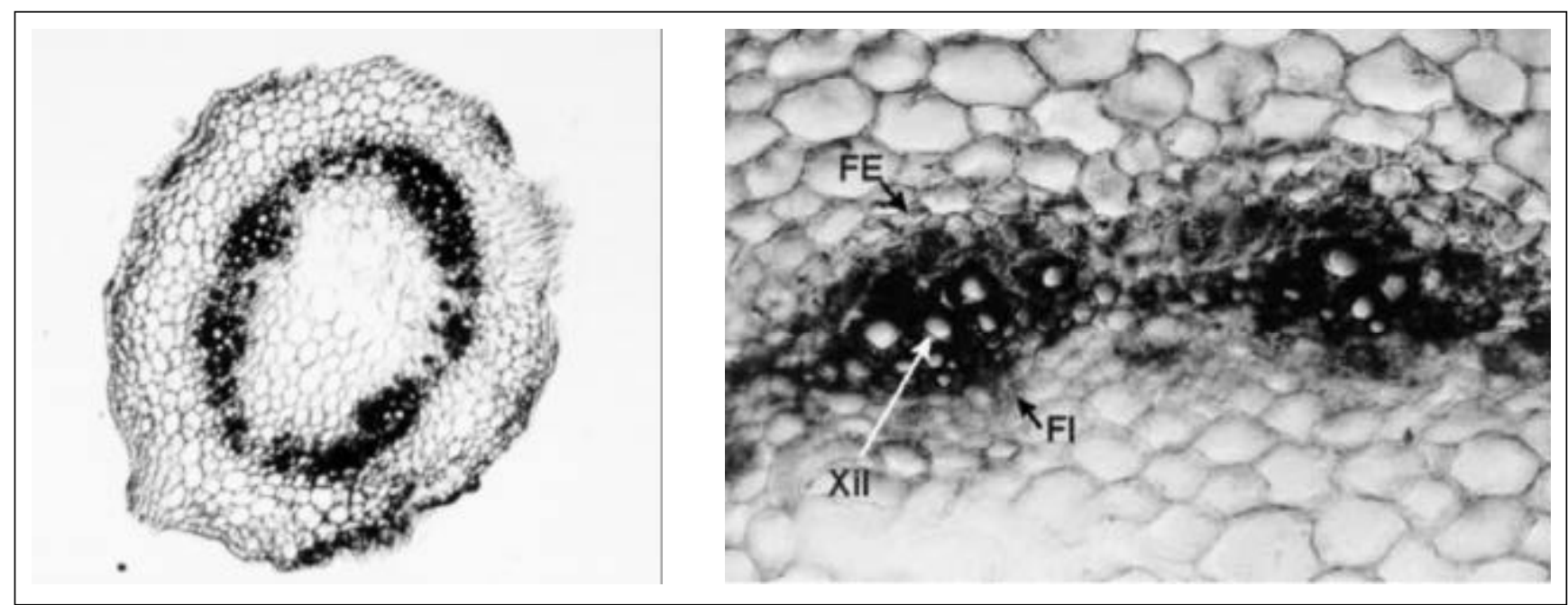

Figura 1. (Esquerda) Corte transversal em caule de batata 'Baronesa', transformadas com o vetor pBRA-gus, mostrando coloração azul na região dos feixes vasculares; (direita) detalhe, mostrando a expressão positiva do gene gus restrita à células do floema e xilema de caule (200x) (FE: floema externo; FI: floema interno; Xil: xilema).

tivares (Baronesa $18 \%$ e Macaca 22\%), quando comparados com explantes foliares (Baronesa 0\% e Macaca 4\%) (Tabela.1). A influência do genótipo na obtenção de plantas transformadas é amplamente reconhecido na literatura (Christou, 1995). Entretanto, essa influência tem sido atribuída mais a variação da performance dos diferentes genótipos durante a cultura de tecidos do que ao processo de transformação genética per se (Ferrer et al., 2000). O melhor potencial morfogenético dos entrenós, quando comparados com explantes foliares confirma dados de outros autores (Wordragen \& Dons, 1992; Torres et al., 2000) e qualifica esses explantes como ideais para transformação. A regeneração de brotações ocorreu, predominantemente, na porção apical dos entrenós. Também foi verificado que nesses explantes houve pouca formação de calo, reduzindo assim a possibilidade de aparecimento de variantes somaclonais.

Análise da expressão do gene gus mediante ensaio histoquímico

A expressão determinada pelo promotor pBRA3, detectada pela atividade da $\beta$-glucuronidase foi observada nas brotações regeneradas, em meio seletivo, em ambas cultivares, restringindose aos feixes vasculares de caules e pecíolos (Figura 1). O sistema vascular dos caules transformados coraram intensamente com o substrato X-Glu, en- quanto o das plantas-controle, não-transformadas, mantiveram-se incolores.

Não foi observada a expressão do gene gus em raízes, rizomas ou mesmo nos tubérculos propriamente ditos. A atividade do gene gus, por vezes, foi verificada somente no sistema vascular das porções distais dos tubérculos em continuidade ao caule subterrâneo. A ausência da coloração nos tubérculos talvez possa ser explicada pelo crescimento diferenciado dos tecidos nesses órgãos. Embora os tubérculos possam apresentar algum grau de crescimento secundário, ele é inexpressivo, e a grande massa de tecido de reserva é produzida pela divisão das células parenquimáticas nas regiões medular e perimedular, fazendo com que os floemas internos e externos fiquem extremamente dispersos pelo órgão (Esau, 1977), e portanto, difíceis de se detectar. Por outro lado, a ausência de coloração, também, nos rizomas e raízes, estruturas igualmente, subterrâneas, sugere que a expressão do gene gus esteja ligada somente às porções aéreas das plantas de batata.

Resultados semelhantes foram obtidos por Carneiro \& Vilaine (1993) em fumo, onde foi observado que o domínio $\mathrm{C}$ do promotor rolA, sozinho, foi capaz de expressar o gene gus nos tecidos vasculares do caule de plantas dessa espécie, de maneira específica, com uma expressão reduzida no floema in- terno das folhas e nenhuma atividade detectável em raízes. A despeito do floema-especificidade do promotor pBRA3, a sua atividade não se restringiu ao floema, dos quais o externo corou mais intensamente, manifestandose também nos espessamentos de parede do xilema de ramos jovens. Há duas hipóteses para explicação desse fato. A primeira é a de que a $\beta$-glucuronidase produzida nas células do floema tenhase difundido para os elementos traqueais jovens, ainda em diferenciação. Uma segunda hipótese, mais provável, é a de que a $\beta$-glucuronidase contida nas células do floema tenham-se liberado quando da secção dos cortes e difundido apoplasticamente, até o xilema, associando-se a celulose, as hemiceluloses, as pectinas, todas essas substâncias hidrofílicas e fortemente, presente nos espessamentos secundários de paredes dos elementos traqueais.

Do ponto de vista fenotípico a morfologia das plantas de batata transgênicas com o promotor rolA (BRA3) foi considerada normal quando comparadas a das plantas não-transformadas, não ocorrendo o encurtamento dos entrenós.

\section{PCR das plantas resistentes à canamicina}

Seis transformantes (três de cada cultivar) expressando o gene gus foram selecionados para análise de DNA, utilizando-se oligonucleotídeos 
flanqueadores da seqüência específica do gene $n p t$ II. Os fragmentos de DNA amplificados a partir do DNA total das plantas gus positivas apresentaram o padrão esperado de $410 \mathrm{pb}$ do gene neo (npt II), enquanto que o controle não desenvolveu amplificação (Figura 2). A planta 2 mostrou uma amplificação tênue.

A alta freqüência de transformantes (confirmados por PCR) garante que a metodologia de transformação e regeneração empregada é eficiente. Além disso, o sistema de seleção utilizado apresentou performance superior a obtida por Campos et al. (1995), devido ao método de co-cultivo diferenciado utilizado e a seleção precoce, diminuindo, assim, o risco de produção de quimeras.

A expressão floema-específica de genes em batata terá um amplo potencial de utilização com genes de resistência a doenças que afetam exclusivamente o tecido vascular.

\section{AGRADECIMENTOS}

Agradeçemos ao $\mathrm{CNPq}$ as bolsas concedidas. Os autores agradecem também pela revisão do texto aos Drs. Leonardo Boiteux e Maria Esther Fonseca (Embrapa Hortaliças).

\section{LITERATURA CITADA}

CARNEIRO, M.; VILAINE, F. Differencial expression of the rol A plant oncogene and its effect on tobacco development. The Plant Journal, v. 3, p. 785-792, 1993.

CAMPOS, M.A. Sistemas de transformação de batata (Solanum tuberosum L.) cultivar Baronesa mediado por Agrobacterium tumefaciens. Pelotas: UFPel, 1995. 93 p. (Tese mestrado)

CHRISTOU, P. Strategies for variety independent genetic transformation of important cereals, legumes and woody species utilizing particle bombardment. Euphytica, v. 85, p. 13-27, 1995. EDWARDS, K.; JOHNSTONE, C.; THOMPSON, C. A simple and rapid method for the preparation of plant genomic DNA for PCR analysis. Nucleic Acids Research, v. 19, p. 1349, 1991.

ESAU, K. Anatomy of seed plants. 2. ed. New York: John Wiley, 1977, 549 p.

FERRER, E.; LINARES, C.; GONZÁLES, J.M Efficient transient expression of the $\beta$ glucuronidase reporter gene in garlic (Allium sativum L.). Agronomie, v. 20, p. 869-874, 2000

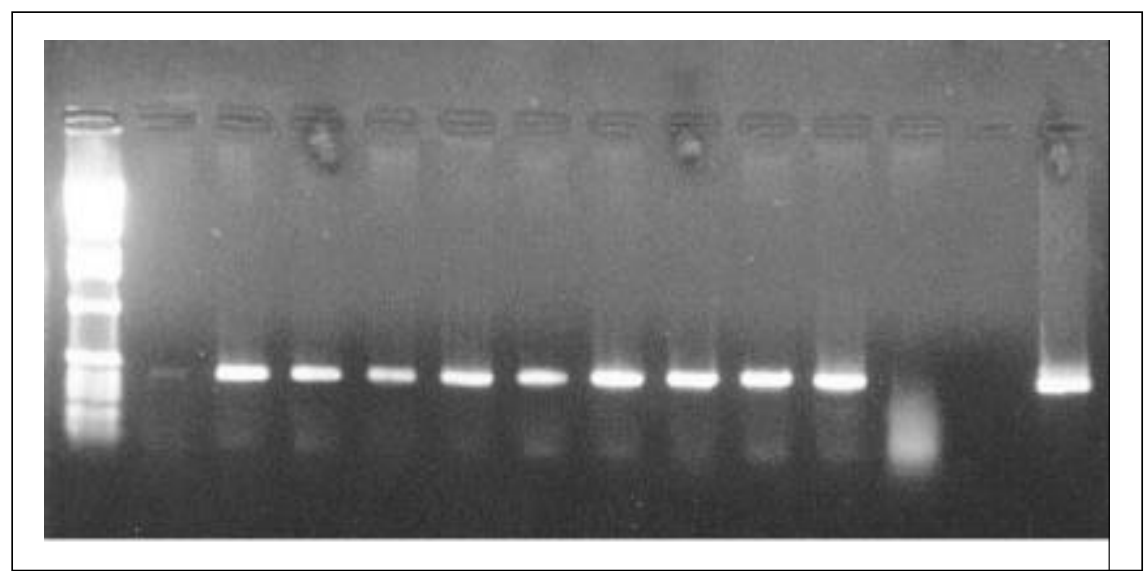

Figura 2. Fragmentos amplificados por PCR utilizando primers específicos do gene neo que codifica para resistência à canamicina (pBRA3-gus). 1 marcador de massa molecular para DNA (1 kb ladder); 2 a 6 plantas transformadas da cultivar Macaca; 7 a 11 plantas transformadas da cultivar Baronesa; 12 planta não transgênica; 13 água; 14 plasmídeo da construção. A planta 2 mostrou uma tênue amplificação. Brasília, Embrapa Hortaliças, 2002.

FIELD, L.M.; FOSTER, S.P. Amplified esterase genes and their relationship with other insecticide resistance mechanisms in english field populations of the aphid, Myzus persicae (Sulzer). Pest Management Science v. 58, n. 9, p. 889-894, 2002 GREEN, A.E.; ALISON, R.F. Recombination between viral RNA and transgenic plant transcripts. Science, v. 263, p. 1423-1425, 1994. GUGERLY, P. Potato viroses. In: BERGMEYER, H.U., ed. Methods of enzymatic analysis: antigens and antibody. Heidelberg: VCH, 1986. v. 11, p. 430-446.

GUIVARC'H, A.; CARNEIRO, M.; VILAINE, F.; PAUTOT, V.; CHRIQUI, D. Tissue-specific expression of the rolA gene mediates morphological changes in transgenic tobacco. Plant Moecular Biology, v. 30, p. 125-134, 1996. HARRISON, B.D. Potato leafroll virus. In: GIBBS, A.J.; HARRISON, B.D.; MURANT, A.F., ed. Descriptions of plant viroses, CMI/AAB, n. 291, 7 p. 1984.

JEFFERSON, R.A.; KAVANAGH, T.A.; BEVAN, M.W. GUS fusions: B-glucuronidase as a sensitive and versatile gene fusion marker in higher plants. EMBO Journal, v. 6, p. 3901-3907, 1987.

MURASHIGE, T.; SKOOG, F. A revised medium for rapid growth and bio assays with tobacco tissue cultures. Physiologia Plantarum, v. 15, p. 473-497, 1962.

ROMANO, E.; FERREIRA, A.T.; DUSI, A.N.; PRITE, K.; ÁVILA, A.C.; NISHIJIMA, M.; NASCIMENTO, A.S.; BRAVO-ALMONACID F., MENTABERRY, A.; MONTE, D.; CAMPOS, M.A.; MELO, P.E.; CATTONY, M.K.; TORRES, A.C. Extreme resistance to two Brazilian strains of Potato virus Y (PVY) in transgenic potato, cv. Achat, expressing the $\mathrm{PVY}^{\circ}$ coat protein. Horticultura Brasileira, Brasília, v. 19, p. 118-122, 2001.
SASS, J.E. Elements of botanical microtechnique. New York: Mc. Graw-Hill Book Company Inc. 1940. 222 p.

SCHMULLING, T.; SCHELL, J.; SPENA, A. Single genes from Agrobacterium rhizogenes influence plant development. EMBO Journal, v. 7, p. 2621-2629, 1988

TAMADA, T.; HARRISON, B.D. Quantitative studies on the uptake and retention of potato leafroll virus by aphids in laboratory and field conditions. Annals Applied Biology, v. 98, p. 261276, 1981.

TORRES, AC; FERREIRA, AT; ROMANO, E; CATTONY, M.K. NASCIMENTO, A.S. Transformação genética da batata cultivar Achat via Agrobacterium tumefaciens. Horticultura Brasileira, Brasília, v. 18, n. 1, p. 41-45, 2000.

TRINCA, S.; DE PACE, C.; CACCIA, R.; MUGNOZZA, G.S.; DODDS, J.H. JAYNES, J. Transformation of potato (Solanum tuberosum L.) leaf disc using A. tumefaciens transfer DNA sequences coding for lytic peptides. Molecular methods for potato improvement. Lima: CIP, 1991. $188 \mathrm{p}$

VAYDA, M.E.; BELNAP, W.R. The emergence of transgenic potatoes as commercial products and tools for basic science. Transgenic Research, v. 1, p. $149-163,1992$.

WORDRAGEN, M.F.V.; DONS, H.J.M Agrobacterium tumefaciens: mediated transformation of recalcitrant crops. Plant Molecular Biology Reports, v. 10, p. 12-36, 1992. 